\title{
Elected Council Installed
}

$\mathrm{T}$ HE MEMBERS of the newly-elected Council of The Oceanography Society were formally installed during the business meeting held in Monterey on August 29, 1989. The ceremony culminated the process, begun at the Society's inception, of assuring a broad-based and democratic governance of the Society. In addition, the Draft Bylaws of the Society were approved by the membership, formally putting into effect the guiding document for the new Council. At the same time, the Interim Council, which had drafted the Bylaws and the Society's Articles of Incorporation, was dissolved, completing the transfer of authority and responsibility to the elected representatives of the membership.

As described in the Bylaws, the President and President-Elect each serve two year terms, whereas the six additional counselors serve staggered three-year terms. Appointed officers may include an Executive Officer, a Corporate Secretary, a Treasurer, and an Editor of Publications, all of whom serve ex-officio without the power to vote.

Abbreviated biographies are given below for the President, D. James Baker, and President-Elect, Arnold L. Gordon. In addition, the members of the Interim and Elected Councils are listed with disciplinary affiliation.

The meeting adjourned after the membership approved a motion thanking the Interim Council for its service and wishing the Elected Council smooth sailing.--DAB President

D. James Baker (B.S. 1958, Stanford University; Ph.D. 1962, Cornell University) is the President of Joint Oceanographic Institutions (JOI) Incorporated in Washington, D.C. He also holds an appointment as Distinguished Visiting Scientist at the Jet Propulsion Laboratory of the California Institute of Technology. Before joining JOI, he was Professor of Oceanography and
Dean of the College of Ocean and Fishery Sciences at the University of Washington. He was elected a Fellow of the American Association for the Advancement of Science in 1988 "for research in ocean circulation and air-sea interaction, and for initiating and coordinating major programs in marine science from ocean drilling to satel-

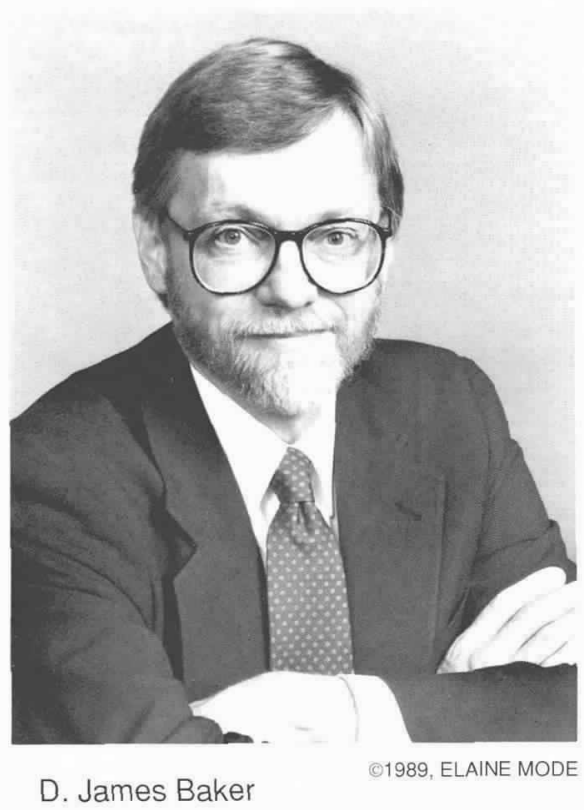

lites." He has published more than seventy papers on ocean circulation, climate, polar oceanography, ocean instruments, and satellites and holds a joint patent for a deep sea pressure gauge. He has participated in expeditions to most of the major oceans.

$\mathrm{He}$ is a member of the National Academy of Sciences/National Research Council's Committee on Global Change and the Advisory Committee for the International Council of Scientific Unions, and has been a member of the Ocean Studies Board, the Committee on Atmospheric Sciences, the Geophysics Study Committee, the Polar Research Board, and the Space
Science Board. He is co-chairman of the international Science Steering Group for the World Ocean Circulation Experiment (WOCE), and an officer of the Joint Scientific Committee for the World Climate Research Program. He has served on advisory committees for the Arctic Research Commission, the Navy, the National Oceanic and Atmospheric Association, and the Department of Commerce, and the National Aeronautics and Space Administration. He has been a member of the Council of American Meteorological Society, is a member of the American Geophysical Union (AGU), the Marine Technology Society, and the Challenger Society. He also served as Interim President of The Oceanography Society.

\section{President-Elect}

Arnold L. Gordon (B.A. 1961, Hunter College; Ph.D. 1965, Columbia University) is Professor of Physical Oceanography in the Department of Geological Sciences of Columbia University and is a member of the Senior Staff at the University's Lamont-Doherty Geological Observatory, where he heads the Physical Oceanography Section. His dissertation topic dealing with the circulation of the Caribbean Sea was supervised by Professor Georg Wüst. His main research interests are in utilizing a diverse array of tools and techniques to investigate the general circulation and mixing of the ocean. A goal is to understand the global factors responsible for the ocean's thermohaline structure and their vulnerability to change. Specific goals are related to processes within climate sensitive regional settings.

$\mathrm{He}$ is the author of numerous publications, with concentration on southern hemisphere oceanography, often dealing with the southern polar region. He has served on numerous national and international committees and has helped organize many research programs. 


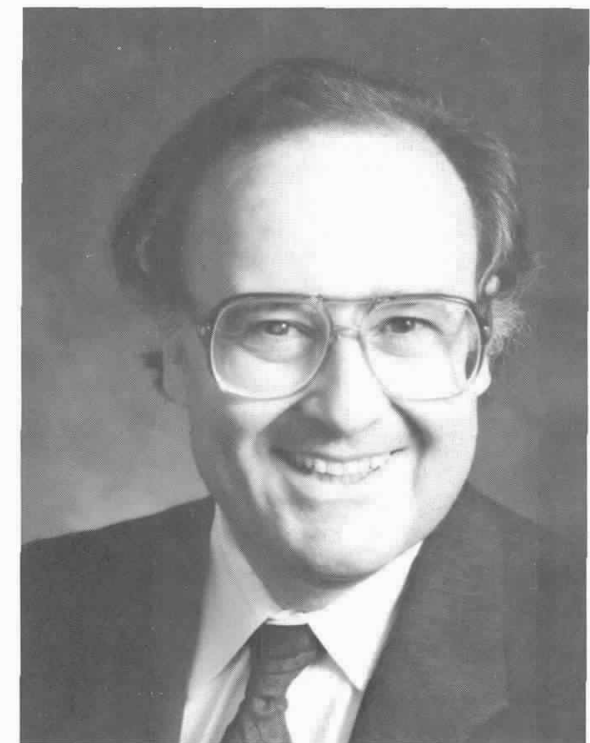

Arnold L. Gordon

Presently, he serves on the Ocean Studies Board of the National Research Council, as Chairman of the Core Project 2 (Southern Ocean) of WOCE, and on the Scientific Steering Committee of the U.S. WOCE Program. He received the U.S. Antarctic Service Medal in 1978; the ninth Henry Bryant Bigelow Medal (awarded by Woods Hole Oceanographic Institution) in 1984; and was elected a Fellow of the AGU in 1989 . $\square$

INTERIM COUNCIL
D. James Baker, Interim President
Neil R. Andersen, Interim Treasurer
Melbourne G. Briscoe, Interim Secretary
Leonard Johnson
Christopher N.K. Mooers
David Schink
David A. Brooks, Editor of Publications,
ex officio
ELECTED COUNCIL
D. James Baker, President
Arnold L. Gordon, President-Elect
Sallie W. Chisholm, Biology
Curtis Collins, Physics
Cindy Lee, Chemistry
H. Thomas Rossby, Applied Technology
Constance A. Sancetta, Geology and
Geophysics
W. Stanley Wilson, At-large

W. Stanley Wilson, At-large

\section{HIGHLIGHTS FROM THE INAUGURAL MEETING OF THE OCEANOGRAPHY SOCIETY Continued From Page 45}

invited speakers, which allowed time for comparatively luxurious development of multidisciplinary topics. The talks were of almost uniformly high quality, and the careful attention to detail and presentation for the most part carried over to the allied poster sessions. Although not promoted as such, an overarching theme of global climate change emerged from the meeting, with highlights on inter-ocean deep water circulation; nutrient, trace-metal and optical control of oceanic productivity; and methods for observing sea-floor spreading centers and long-term global warming. Abstracts for the invited talks and poster papers were printed in the Meeting Program, which is still available for five dollars from TOS headquarters while supplies last.

Students are an important part of the Society, and they played an active role in the meeting. It is fitting that the tradition of recognizing the best student paper was established at Monterey. It was a difficult choice, but the judges, lead by Mary Batteen, awarded the prize to Gary Kirkpatrick from North Carolina State University for his poster, with co-authors, entitled "Measurement of Photosynthetic Response to Euphotic Zone Physical Forcing." Gary's abstract is published elsewhere in this issue, and the full paper will appear in a subsequent issue.

In a moment of spontaneous inspiration, Mel Briscoe presented awards, drawn from a paper sack with pomp and circumstance, for the two posters best reflecting the use of innovative technology. Again it was a daunting choice. The first prize went to Cynthia Pilskaln and Mary Silver, who received a fine specimen of California Cabernet for their paper, "The Role of Marine Snow in the Mid-Water Regeneration Zone: An in situ Study Using an ROV." The "next-first" prize was accepted by Tim Stanton who, in the emerging spirit of multidisciplinary bliss, received a glittering corkscrew for his paper, "Estimation of Reynolds Stresses Using a Bistatic Acoustic Doppler Profiler." It is not known if the relationship was consummated.

The final registration count was 546, not including 85 spouses. The evening at the Aquarium was enjoyed by 563 persons. About 80 persons registered at the meeting, indicating unusual support for a fledgling society, according to our meetings contractor, Ed Pechan. One hundred forty-seven posters were displayed in the three sessions. The last-minute burst of registrations was a fine vote of confidence for the meeting strategy. In the end, the attendance figures exceeded expectations, although there were a few unsettling weeks in the summer doldrums when enrollment lagged in proportion to the afternoon temperatures.

It's difficult to summarize the impact of this meeting from close perspective, and to attempt to do so is to risk sentimentality and fatuousness. Yet, it seems clear that we have been part of a successful experiment born of a determination to-as David Packard admonished- - "do it ourselves," or take the helm of our own vessel. The result produced a special charm and warmth, something akin to the luminosity of a twentieth high school reunion, as one person suggested at the icebreaker gathering. Walter Munk put it closer to our hearts in his closing remarks, given elsewhere in this issue. Paraphrasing, on the final day he said the emotional response to this meeting "is like the feeling one gets after being at sea for three days," which for me means the easy familiarity and close companionship of brothers-in-arms. As Walter said, we all left "elated and a little exhausted." We also learned a little more about the oceans, and maybe about ourselves; and we had a grand time in the process. It will be a treasured experience. $\square$ 